\title{
Education, Economic Situation and Prospects of India, 1971
}

\author{
by Marc Blaug*
}

Structural Trends.

The dominant characteristic of Indian education since independence has been the tendency of higher education to expand faster than and indeed at the expense of primary and secondary education, a terdency which flies in the face of 20 years of verbal comitments to the goal of universal primary education. Consider, as a case in point, the contrast since 1950 between the target and the actual rates of growth of enrolments in various levels of the Indian educational system (sae TABLE 1).

As we can see, the first three Five Year Plans laid down enrolment targets - a practice that has now been abondoned - and in each Plan except the First, the targets were either met or greatly exceeded, the excess being greater the higher the level of education. Furthermore, the targets themselves called for faster expansion of secondary and higher education than of primary and middle education, contradicting statements in every one of the Plan documents that give top priority to primary education in accordance with the provisions of Article 45 of the Indian Constitution. This Article directs the government "to provide, within a period of ten years from the commencement of this constitution (1950), for free and compulsory education for all children until they complete the age of fourteen years". The date has been postponed at various times to 1965, 1975 and 1985. Even by the end of the Fourth Five Year Plan (1974), only $86 \%$ of children aged $6-11$ and only $41 \%$ of children aged 11-14 are expected to be enrolled in primary and middle schools (see TABLE 2). The Fourth

* Professor Blaug is the Director of the Research Unit in Economics of Education, the Institute of Education, University of London. 


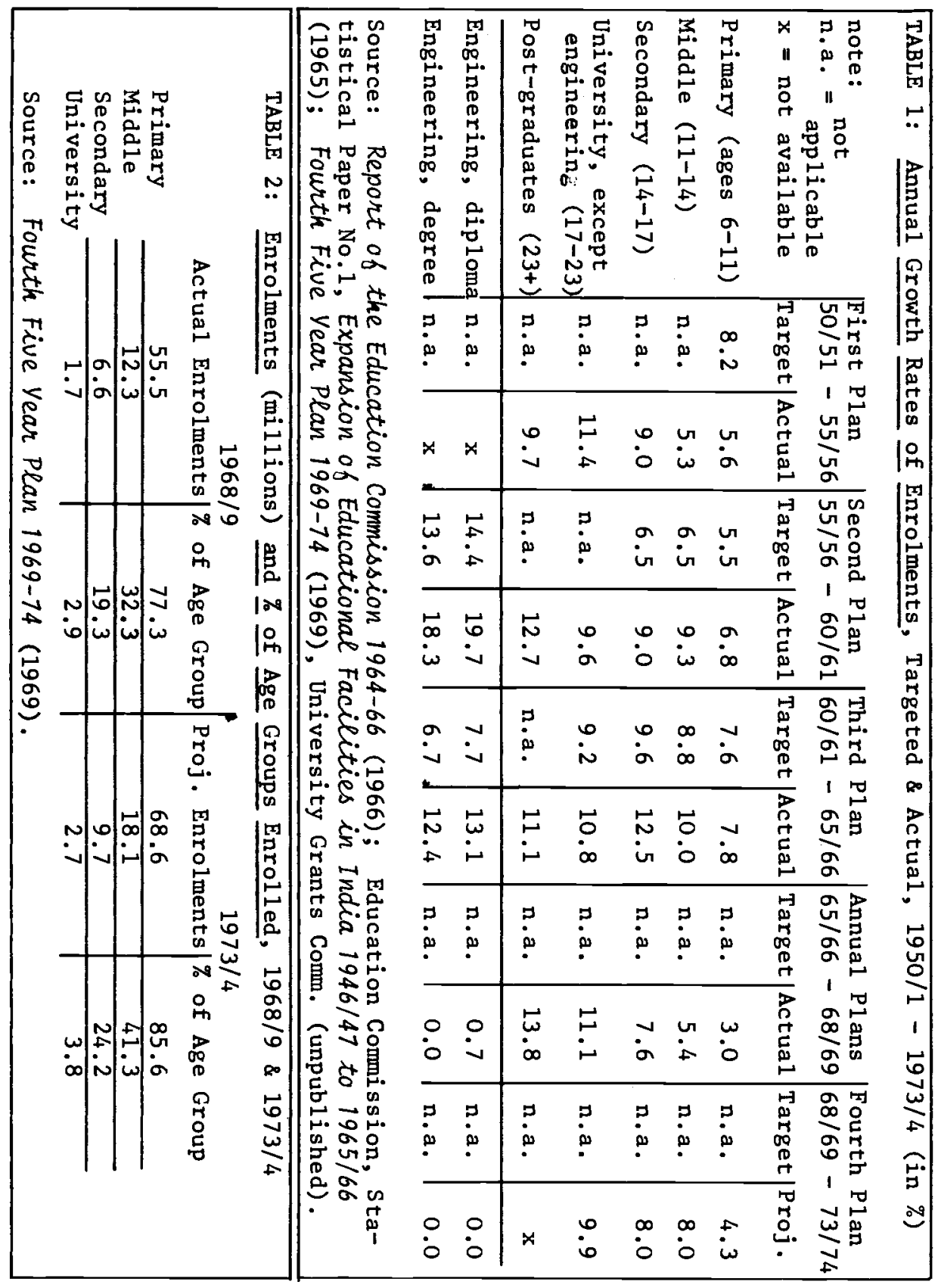


Five Year $\mathrm{Plan}$ once again announces that priority will be given to primary education; nevertheless, primary education is projected to grow at only $4.3 \%$ over the Plan period, while university education is projected to grow at $9.9 \%$.

At this rate, India will be enrolling a higher proportion of the relevant age group in colleges and universities but a lower proportion in primary schools by 1973/4 than Korea, Singapore and the Philippines, Asian economies that have incomes per head eight to ten times that of India. Similarly, India already enrols a much higher proportion of her college-aged population and a much lower proportion of her young children in primary schools than did Japan in 1905, a time when Japan's income level was just about that of India today. Although comparaison n'est pas raison, these figures begin to create the suspicion that India is peculiar among underdeveloped countries in her extraordinary emphasis on higher education.

The fact that an educational plan gives priority to primary education does not necessarily imply that primary education must be made to grow faster than higher education. It is conceivable that the expansion of primary education requires the prior growth of teacher training which is counted as part of secondary and of higher education. Unfortunately, this argument does not carry much weight in the Indian situation where less than a quarter of the employed matriculates and graduates are teachers: it would be perfectly possible to increase the output of teachers without requiring secondary and higher education to grow faster than primary and middle schooling. Then again, if higher education were cheaper than primary education, there would be no contradiction between a stated objective that accords priority to primary education and a policy that permits the faster expansion of higher education. But the average cost of educating an undergraduate in arts and science for one year is 11 times that of educating a primary school pupil and a post-graduate student costs as much per year as 39 primary school pupils. In consequence, the tendency of university enrolments to grow faster than school enrolments has led to a steady shift of expenditure towards the higher levels. In 1950 , India spent $1.2 \%$ of her national income on education, of which primary education constituted $49 \%$ and higher education $23 \%$; in 1965 , India spent 
almost $3 \%$ of her income on education but the share of primary education had by then fallen to $43 \%$ while that of higher education had risen to $29 \%$. In short, although total educational expenditures have grown faster than national income, university expansion has steadily reduced the share of expenditures going to school education.

It must be conceded that the goal of universal primary education becomes more difficult to achieve the nearer we approach it. In addition, certain stubborn facts beyond the control of educational planners, such as the lack of roads on which to travel to school and the real economic value to parents of young children at home, impede the achievement of $100 \%$ enrolment rates. Nevertheless, other causes of the high wastage rates in Indian primary education - over-crowded classes, inadequately prepared teachers, out-dated curricula, lack of textbooks and equipment, etcetera - can be remedied by spending more money. For example, the education of "scheduled castes" is already being stimulated by means of free textbooks, free uniforms and free midday meals, and no one doubts that the extension of such subsidies to all students would have a significant impact on wastage in primary schools.

It is clear, therefore, that if more resources had been invested in primary education in the past, universal primary education would not have had to be postponed again and again. That this has not happened must be attributed in large part to the resources preempted by the pel1-mell growth of higher education.

The truth is that India has never practiced educational planning in any true sense of the term except in the fields of technical and medical education. The targets of the first three Five Year Plans were merely extrapolations of past trends in enrolments and the fact that they were frequently exceeded simply means that past trends were misread. If educational planning is to be effective, the authorities must be able to resist the private demand for education. But the truth is that the educational authorities of India have never been able to control admission into secondary and higher education. This is precisely why the Fourth Five Year Plan has abandoned the notion of targets for enrolment. The fact that the so-called "targets" of past plans were simply projections of what was considered likely rather than what was considered desirable is now public knowledge, at least among educators. 
The failure to control or to resist the private demand for secondary and higher education and thus to divert additional resources into primary education takes on additional significance when we consider the problem of "educated unemployment". The term "educated" refers to members of the labour force who have at least completed secondary education, that is, some 10 million people in 1970 who are either matriculates or graduates. In a country like India, any single figure for unemployment, whether for educated or for uneducated people, is bound to be misleading: the absence of unemployment compensation forces an infividual who carnot get 3 full-tine job to take whatever part-time work is avoi lable. Instead of a sharp distinction between being smployed and being unemployed, there is a continunus diarribution of people in terms of days worked per week and even hours worked per day. Thus, depending on how conservatively we define unemployment, we can get estimates for the degree of educated unemployment that range from 3 to $13 \%$ of the stock of educated labor (see the Dantwala Committee Report: Report of the Committee of Experts on Unemployment Estimates, 1970). From what is known of casual employment among matriculates and graduates, a figure of about $6-7 \%$ is probably as near to the truth as any single figure can be. This implies a total number of 650,000 educated people who work only a day a week if at all, which is equivalent to more than one third of the current out-turn of matriculates and graduates from schools and colleges in a single year?

It is worth noting that the rate of unemployment appears to rise with additional education up to the level of matriculation, after which it declines for graduates and post-graduates: unemployment is worse among arts and commerce graduates but it is not negligible for science graduates and post-graduates. It is also worth noting that educated unemployment in India constitutes, as it were, a revolving queue: it is not that some are permanently employed and others are unemployed for life, but rather that large numbers have to wait years before finding a job. The number of new jobs is growing all the time but as soon as one cohort has been absorbed, a new cohort comes along to take up the vacant places in the queue. Indeed, on the best available evidence the numbers of educated employed appears to have remained an almost constant proportion 
of the stock of educated people over the whole period 1950 to 1970. In other words, the longterm growth rate of national output of $3.5 \%$ since 1950 has just managed to absorb an out-turn of educated people at an annual rate of about $6 \%$. But it has not been able to make any dent into the backlog of educated unemployment; the explosive growth of secondary and higher education always creates a new backlog as fast as the old one is eliminated.

The persistent tendency of the supply of educated people to run ahead of the demand for them has led to a steady decline in the real earnings associated with educational qualifications. That is to say, there has been sidespread and continuous upgrading of minimum hiring standards in Indian labor markets ever since Independence: jobs that used to be filled by matriculates, such as clerks, typists and bus conductors, now typically call for graduate qualifications. In that sense, unemployment among the educated in India has in fact led to a reduction in their relative earnings, exactly as predicted by economic theory. Nevertheless, earnings have never declined fast enough to reduce the incentives to acquire still more education. As a recent study has shown, (1) secondary and higher education still pay off handsomely to the individual in India, even after allowing for the private costs of education and the possibility of unemployment. Indian labour markets do respond to unemployment but only sluggishly and with very long time lags: there are strong taboos about changing jobs and this alone makes it rational for a new entrant into the labour market to spend a long time finding the best possible job available.

Searching for work is a lengthy process in India's poorly organised labour markets. Despite the rapid growth of labour exchanges around the country since 1950 and despite the increased use of newspapers as a source of information about job vacancies, Indian job seekers still rely to this day on personal contacts as the principal source of job offers, which again tends to lengthen the period of search; lastly, the institution of the "joint family" reduces the incentive of job seekers to cut down on the length of search: unemployed Indian students can depend almost indefinitely on some financial

(1) M. Blaug, R. Layard, M. Woodhall, The causes of Graduate Unemployment in India. (1969). 
support from their families. All of which can be summed up by saying that the persistence of educated unemployment ever since Independence is essentially explained by certain characteristic features of Indian labour markets that slow down the rate of which the unemployed are willing to lower their reservation price.

The fact that education is privately profitable does not tell us whether it is socially profitable. Since education is heavily subsidized in India and since the government recovers little of the extra earnings of the better educated through income taxes, one would expect the social rate of return on educational investment to fall below the private rate of return. Such is indeed the case at all levels of education. More to the point, that social rate of return falls steadily as we move up the educational ladder: it is about $19 \%$ on primary education but it is only $10 \%$ on university education (the figures are adjusted for the probability of unemployment and wastage at the various levels and for the proportion of earnings which are due to better-than-average home background). This fact alone argues for a re-allocation of a given budget for education towards primary education. Even if we drop the assumption of a given budget for education and compare the rates of return on educational investment with the yield of other public investment, it is impossible to justify continued expansion of higher education. The social rate of return on higher education is distinctly less than the target rates of return of $12 \%$ which are required of public sector enterprises in the Fourth Five Year Plan. Even the rate of return on secondary education is only just on the border-line of being acceptable. It is difficult to resist the conclusion, therefore, that higher education in India is badly overexpanded.

About three-quarters of all graduates and almost three-quarters of matriculates work in the public sector, whereas the bulk of primary-school leavers work in the private sector. It is very likely that the public sector "hoards" educated people, which is equivalent to saying that it pays them more than their marginal productivity. In that case, the true social rate of return on investment in higher education is even less than $10 \%$, which doubles the force of our previous conclusion. Even if education generates significant externalities which are not adequately reflected in earnings and hence in rate-of-return calculations, one has to believe that the magnitude of these externalities 
are much greater at the higher than at the lower levels of education to reverse the conclusion of over-investment in higher education. In a country like India, which has an average literacy rate of $30 \%$, this does not strike us as a tenable proportion.

The entire argument up to this point simply takes for granted the idea that education is conducted to serve the goal of maximizing the growth of national income. But although this is one of the stated objectives of Indian education, the authorities have never lost sight of other objectives, such as equality of educational opportunity, political stability and national integration. There is very little solid evidence on the social class origins of Indian students but the Report on the Pattern of Graduate Employment (1963) and some data gathered by the Education Commission 1964-66 suggest that the bulk of undergraduates are members of families whose incomes lie in the upper two deciles of the urban income distribution and in the upper decile of the rural income distribution. Thus, if the goal is equity rather than efficiency, there is little doubt that too much of the educational budget has gone to the higher levels and too little to the lower levels of the educational system. Likewise, it would strain credulity to argue that the reduction of regional and communal strife is better served by producing more matriculates and graduates, many of whom will be unemployed, than by producing more people with at least four or five years of schooling, which seems to be the minimum amount required to achieve functional literacy through life. In short, if equality, political stability and social cohesion in India can be promoted by education, the optimum strategy is once again to divert resources from the higher to the lower levels. It is perfectly true that to deny higher education to a matriculate will not by itself cure the unemployment problem; it only converts graduate unemployment into matriculate unemployment. But it does release resources for other uses and so long as resources are scarce, to provide education for one more university student means denying it to eleven primary school pupils.

There is a further problem about the growth of higher education in India that we can only allude to here, namely the problem of quality. Any educational system which is growing at an accelerated rate will experience shortages of good teachers and a system which is growing faster at the top than at the bottom will 
steadily deprive the lower schools of the best teachers. After some time, however, the rot will pass up through the system eventually contaminating the quality of higher education. In the view of many Indian educators, "a large segment of higher education in India has become a caricature of what higher education is supposed to be" (to quote K.N. Raj in his 1970 Patel Memorial Lecture, "Crisis of Higher Education in India") and the Indian Education Commission Report 1964-66 made no bones about the fact that an Indian B.A. is generally regarded outside India as barely equivalent to an American high school diploma. The decline in standards is only partly the result of accelerated growth, in addition, there was the unwillingness to finance expansion at the same accelerated rate. Thus, the real salaries of university and college teachers actually fell between 1950 and 1965, a period when real income per head in India rose by $21 \%$. If the salary position of teachers is to be improved in the future as an integral part of the effort to raise quality, the pressures on resources will multiply. The question takes on new significance in view of the cut-backs in educational expenditure in the present Fourth Five Year Plan to $5.8 \%$ of total planned outlays, the smallest allocation ever given to education. As the Ministry of Education frankly concedes, "The axe has fallen very heavily on primary education in particular and generally on all programmes of qualitative improvement" (Ministry of Education Report 1969-70).

The case for cutting back the growth of secondary and higher education in India is overwhelming but the instruments for actually enforcing this policy are few. In the practical circumstances of Indian politics, it would be suicidal for State Governments to institute a selective admissions policy. It might be possible, however, to gradually raise tuition fees from the average current level of Rs. 250 to the full costs of Rs. 750 (the figures refer to art and science colleges) in an effort to reduce the private rate of return to higher education; if this were accompanied by the more vigorous use of scholarship programs for poor students, it is likely that it could be made politically acceptable to the Indian electorate, at least after a preliminary propaganda campaign. Another suggestion, which has been mooted in Indian educational circles, is to select people for public service jobs before they go to ccllege, while at the same time making their appointment conditional 
on their getting a satisfactory degree. Be that as it may, the problem is at least in principle capable for solution in so far as the government is itself the principal employer of highly-educated people. At any rate, until it is solved, most of the other improvements that are currently being put into effect in Indian education are unlikely to make much difference.

\section{Current Problems.}

The best way of reviewing current developments in Indian education is to ask what has become of the recommendations of the Report of the Education Commission 1964-66 (1966). At the center of all their proposals, is that of introducing a "policy of selective admissions" in secondary and higher education; in their own words, "to restrict the unplanned and uncontrolled expansion of general secondary and higher education, if massive educated unemployment is to be avoided; to make special and intensive efforts to vocationalize secondary education and to develop professional education at the university stage".

The Commission was driven to the conclusion that the proportion of middle school leavers who go on to secondary school, and matriculates who proceed to colleges and universities, would have to fall.(1) They called for an end to the open-door policy in higher education, amounting in fact to a relative declaration of the rate of growth of enrolments in higher education. However, they did not spell out any measures by which this could be achieved. In particular, they did not recommend any upward revision of fees. On the contrary, after recommending abolition of fees in all primary and middle schools, they also proposed to abolish them for "needy students" in secondary and higher education over the next ten years to the point where $30 \%$ of students would not be paying fees of any kind.

But, the fundamental proposal of the Education Commission to slow down the expansion of higher education has fallen on deaf ears and the prevailing attitude in India to educated unemployment continues to be a

(T) Unless this happened, they predicted that there would be 4 million unemployed matriculates and 1.5 . million unemployed graduates by 1986 . 
complacent one. Thus the Fourth Five Year Plan document has no qualms about the proposition that "there are greater risks of loss when such available shortages (of manpower) arise then when there is a marginal surplus of trained manpower". This seems entirely to ignore the real cost to society of producing educated people who will be unemployed.

The major problems of Indian education remain surely:

(1) the heavy wastage in primary and middle education;

(2) the uncontrolled expansion of secondary and higher education;

(3) the massive illiteracy of the adult population;

(4) the enormous inequalities in educational provision between different States and between different districts within States; and

(5) the appallingly low quality of all education, accompanied by the failure of quality significantly to improve over time.

If these are the outstanding problems, it is difficult to find any coherent plan for tackling them in the current battery of educational policies. The Education Commission Report may have had its weaknesses but its recommendations did add up to some unified approach to Indian education. It is this unified approach, and not so much any specific recommendation, which seems to have been largely abandoned since the Commission reported in 1966. 